\section{Edubiotik : Jurnal Pendidikan, Biologi dan Terapan \\ ISSN 2528-679X (print), ISSN 2597-9833 (online) \\ Volume 5, Nomor 01, Tahun 2020, Hal. 71 - 80 \\ Available online at: \\ http://ejurnal.budiutomomalang.ac.id/index.php/edubiotik}

Research Article

\title{
Analisis vegetasi tumbuhan angiospermae di desa ranga-ranga kecamatan masama kabupaten banggai
}

\author{
Nurlia, Wahyudin Abd. Karim
}

Program Studi Pendidikan Biologi, Universitas Muhammadiyah Luwuk, Banggai, Indonesia

E-mail: nurlia2811@gmail.com*, wahyudinabdulkarim87@gmail.com

\begin{tabular}{|c|c|}
\hline Informasi Artikel & ABSTRACT \\
\hline $\begin{array}{l}\text { Submit: } 16-01-2020 \\
\text { Diterima: } 25-02-2020 \\
\text { Dipublikasikan: } 27-02-2020\end{array}$ & $\begin{array}{l}\text { The structure and composition of vegetation are influenced by different types of plants, so } \\
\text { vegetation constituent data is needed to determine the diversity of plant species. The purpose } \\
\text { of this study was to determine the structure and composition of Angiosperms plant vegetation } \\
\text { constituents in Ranga-ranga Village. The research method used was experimental with a type } \\
\text { of exploratory descriptive research using a plot line method of } 20 \text { plots. The research } \\
\text { instrument was an observation sheet. Research data namely the type and number of plants. } \\
\text { Quantitative descriptive data analysis techniques to obtain the value of relative frequency, } \\
\text { relative density, relative dominance, and index of important values. The results showed that } \\
\text { the highest relative frequency of A. occidentale (FR =31.03\%), the lowest was R. communis, } \\
\text { M. sago, A. carambola, T. cacao, M. indica, A. heterophyllus, S. lineatum, C. pulcherrima, } \\
\text { and M. calabura (FR = 1.29\%). The highest relative density of C. rotundus (KR = 31.39\%), } \\
\text { the lowest C. pulcherima and C. Arabica (KR = 0.89\%). The highest relative dominance of T. } \\
\text { grandis (DR = 16.15\%), the lowest M. indica (DR = 4.67\%). The highest importance index is } \\
\text { A. occidentale (INP = 59.85\%), the lowest is R. communis, A. carambola, M. indica, A. } \\
\text { heterophyllus, C. pulcherrima, and M. calabura (INP = 2.33\%). The conclusion of the } \\
\text { research is the structure and composition of Angiosperms plants vegetation in Ranga-ranga } \\
\text { Village, varying at the level of trees, poles, saplings, and seedlings. } \\
\text { Key words: Angiospermae, Ranga-ranga village, Vegetation analysis }\end{array}$ \\
\hline Penerbit & ABSTRAK \\
\hline $\begin{array}{l}\text { Program Studi Pendidikan Biologi, } \\
\text { IKIP Budi Utomo, Malang, Indonesia }\end{array}$ & $\begin{array}{l}\text { Struktur dan komposisi vegetasi dipengaruhi oleh keanekaragaman jenis tumbuhan, } \\
\text { sehingga dibutuhkan data penyusun vegetasi untuk mengetahui keanekaragaman jenis } \\
\text { tumbuhan. Tujuan penelitian adalah untuk mengetahui struktur dan komposisi penyusun } \\
\text { vegetasi tumbuhan Angiospermae di Desa Ranga-ranga. Metode penelitian adalah } \\
\text { eksperimental dengan jenis penelitian deskriptif eksploratif menggunakan metode garis } \\
\text { berpetak sebanyak } 20 \text { petak. Instrumen penelitian adalah lembar observasi. Data penelitian } \\
\text { yaitu jenis dan jumlah tumbuhan. Teknik analisis data berupa deskriptif kuantitatif untuk } \\
\text { memperoleh nilai frekuensi relatif, kerapatan relatif, dominasi relatif, dan indeks nilai penting. } \\
\text { Hasil penelitian menunjukkan bahwa frekuensi relatif tertinggi pada tanaman } A \text {. occidentale } \\
\text { (FR=31,03\%), terendah } R \text {. communis, } M \text {. sagu, A. carambola, T. cacao, M. indica, A. } \\
\text { heterophyllus, S. lineatum, C. pulcherrima, dan M. calabura (FR=1,29\%). Kerapatan relatif }\end{array}$ \\
\hline 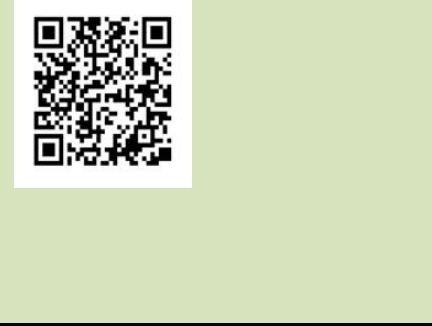 & $\begin{array}{l}\text { tertinggi pada C. rotundus (KR=31,39\%), terendah C. pulcherima dan C. Arabica } \\
(\mathrm{KR}=0,89 \%) \text {. Dominansi relatif tertinggi T. grandis }(\mathrm{DR}=16,15 \%) \text {, terendah M. indica } \\
(\mathrm{DR}=4,67 \%) \text {. Indeks Nilai Penting tertinggi A. occidentale }(\mathrm{INP}=59,85 \%) \text {, terendah } R \text {. } \\
\text { communis, A. carambola, M. indica, A. heterophyllus, C. pulcherrima, dan M. calabura } \\
(\mathrm{INP}=2,33 \%) \text {. Simpulan penelitian yaitu struktur dan komposisi vegetasi tumbuhan } \\
\text { Angiospermae di Desa Ranga-ranga beranekaragam pada tingkat pohon, tiang, pancang, } \\
\text { dan semai. } \\
\text { Kata Kunci: Analisis vegetasi, Angiospermae, Desa ranga-ranga }\end{array}$ \\
\hline
\end{tabular}

This Edubiotik : Jurnal Pendidikan, Biologi dan Terapan is licensed under a CC BY-SA (Creative Commons AttributionShareAlike 4.0 International License) 


\section{PENDAHULUAN}

Indonesia terletak di daerah tropik sehingga memiliki keanekaragaman hayati yang tinggi dibandingkan dengan daerah subtropik dan kutub. Tingginya keanekaragaman hayati di Indonesia dapat dilihat dari berbagai macam ekosistem yang ada. Masing-masing ekosistem memiliki keanekaragaman hayati tersendiri (Ridhwan, 2012). Hutan Indonesia merupakan salah satu pusat keanekaragaman hayati di dunia. Keanekaragaman tersebut meliputi tumbuhan dan hewan yang tersebar di seluruh wilayah Indonesia. Indonesia menempati urutan keempat di dunia untuk keanekaragaman jenis tumbuhan, yaitu memiliki kurang lebih 38.000 jenis. Keanekaragaman jenis tumbuhan tersebut dapat terlihat pada hutan-hutan yang tersebar di seluruh kawasan Indonesia (Indrawan, 2007).

Hutan merupakan habitat plasma nutfah dari berbagai jenis tumbuhan (flora) dan hewan (fauna). Jika hutan mengalami kerusakan, maka dapat dipastikan akan terjadi erosi plasma nutfah yang berakibat punahnya berbagai kehidupan yang ada di hutan serta menurunnya keanekaragaman hayati (Indriyanto, 2012). Potensi hutan berupa keanekaragaman hayati tersebut perlu dikaji, karena keanekaragaman hayati berupa potensi vegetasi sangat berperan terhadap suatu ekosistem yang terkait dengan pengaturan keseimbangan karbondioksida dan oksigen di udara, perbaikan sifat fisik, kimia dan biologis tanah, pengaturan tata air tanah, dan lain sebagainya (Djamal \& Irwan, 2012). Berdasarkan kondisi lingkungannya, flora (tumbuhan) di suatu tempat terdiri dari beragam jenis, di mana masing-masing terdiri dari beragam variasi gen yang hidup di beberapa tipe habitat. Keanekaragaman flora mencakup keanekaragaman jenis, keanekaragaman genetik, dan keanekaragaman habitat, dimana jenis-jenis flora tersebut tumbuh (Kusmana \& Hikmat, 2015).

Desa Ranga-ranga memiliki hutan dengan berbagai macam jenis tumbuhan. Keanekaragaman tumbuhan yang ada dapat mempengaruhi struktur dan komposisi vegetasi di daerah tersebut. Oleh karena itu, dibutuhkan penelitian untuk mengumpulkan data penyusun vegetasi tumbuhan yang ada di hutan Desa Ranga-ranga Kecamatan Masama Kabupaten Banggai. Luas kawasan hutan di Desa Ranga-ranga mencapai $625 \mathrm{Ha}$ atau $75,85 \%$ dari total wilayah administratif (Pemdes Ranga-ranga, 2019). Kawasan hutan tersebut terdiri dari hutan mangrove, hutan primer dan hutan sekunder. Lokasi yang dipilih sebagai tempat penelitian berada di daerah perbukitan, dengan ketinggian sekitar $23 \mathrm{mdpl}$, dengan iklim cenderung panas karena merupakan dataran rendah dan jaraknya tidak jauh dari kawasan hutan mangrove. Di daerah tersebut terdapat sumber mata air yang mendukung kelangsungan makhluk hidup yang ada di sekitarnya terutama tumbuhan. Berdasarkan hasil observasi awal, keanekaragaman tumbuhan di daerah tersebut sangat bervariasi dan yang paling banyak didominasi oleh tumbuhan Angiospermae. Faktanya, di hutan Desa Ranga-ranga belum ada data mengenai jenis vegetasi yang ada dan belum pernah dilakukan penelitian terkait struktur dan komposisi penyusun vegetasi tumbuhan di daerah tersebut.

Analisis vegetasi terhadap hutan perlu dilakukan untuk mengetahui keanekaragaman hayati yang terdapat di hutan tersebut sehingga mempermudah dalam melakukan pemeliharaan dan pemberdayaan hutan. Analisis vegetasi memerlukan data jenis, jumlah, dan diameter tumbuhan untuk menentukan indeks nilai penting sehingga memperoleh informasi kuantitatif tentang struktur dan komposisi suatu komunitas tumbuhan (Heriyanto \& Subiandono, 2016). Unsur struktur vegetasi terdiri atas bentuk pertumbuhan, stratifikasi, dan tajuk (Asmayannur, 2012). Indriyanto (2012) menjelaskan bahwa deskripsi suatu vegetasi diperlukan beberapa parameter kuantitatif antara lain densitas (kerapatan), frekuensi, dominansi (dominance), indeks nilai penting (important value index), dan indeks keanekaragaman (index of diversity). Penelitian sebelumnya terkait struktur dan komposisi vegetasi 
Angiospermae di Taman Wisata Wira Garden Lampung hanya pada vegetasi kategori pohon dan kategori tiang (Umar, 2012). Penelitian lainnya yaitu keanekaragaman jenis tumbuhan Angiospermae di kebun biologi Seungko Mulat hanya pada tumbuhan yang berhabitus herba, semak, dan pohon (Taib \& Dewi, 2013). Penelitian struktur vegetasi dan keanekaragaman tumbuhan di kawasan Daerah Aliran Sungai (DAS) Krueng Jreue hanya pada habitus herba (Susanti, 2016). Berdasarkan uraian diatas, maka analisis vegetasi tumbuhan pada semua tingkatan pertumbuhan yaitu pohon, tiang, pancang dan semai masih perlu dilakukan. Potensi hutan yang ada di desa Ranga-ranga cukup memadai dan memiliki karakteristik vegetasi yang berbeda dari hasil penelitian sebelumnya. Hal itu disebabkan karena setiap daerah mempunyai ciri khas tumbuhan dan kondisi lingkungan yang berbeda. Dengan demikian, tujuan penelitian ini yaitu untuk mengetahui struktur dan komposisi penyusun vegetasi tumbuhan Angiospermae di Desa Ranga-ranga Kecamatan Masama Kabupaten Banggai.

\section{METODE PENELITIAN}

Jenis penelitian ini adalah penelitian deskriptif eksploratif. Penelitian deskriptif eksploratif digunakan untuk memaparkan atau menggambarkan keadaan, kondisi, situasi, peristiwa, kegiatan, dan lain-lain (Suryabrata, 2013). Penelitian ini dilaksanakan pada bulan April tahun 2019, di kawasan hutan Desa Ranga-ranga Kecamatan Masama Kabupaten Banggai. Alat dan bahan yang digunakan dalam penelitian ini antara lain alat tulis, tali rafia, meteran, patokan kayu, kamera, parang, buku identifikasi. kantong plastik, kertas koran, dan kertas label. Penelitian dilakukan menggunakan metode garis berpetak, dengan petak berukuran $20 \mathrm{~m} \times 20 \mathrm{~m}$ dan jarak antar petak adalah $20 \mathrm{~m}$, yang diletakkan sepanjang jalur pengamatan yang berkuran $4 \times 200 \mathrm{~m}$. Masing-masing jalur pengamatan terdiri atas 5 petak sehingga jumlah petak yang digunakan dalam penelitian sebanyak 20 petak contoh. Dalam masing-masing petak contoh tersebut dibuat sub petak contoh ukuran $10 \mathrm{~m} \times 10 \mathrm{~m}$, dalam petak contoh tersebut dibuat lagi sub petak ukuran $5 \mathrm{~m} \times 5 \mathrm{~m}$ dan dalam petak contoh tersebut dibuat lagi sub petak ukuran $2 \mathrm{~m} \times 2 \mathrm{~m}$. Petak contoh ukuran 20m x 20m digunakan untuk mengumpulkan data jenis pohon, petak ukuran $10 \mathrm{~m} \times 10 \mathrm{~m}$ untuk mengumpulkan data jenis tiang, petak contoh ukuran $5 \mathrm{~m} \times 5 \mathrm{~m}$ untuk mengumpulkan data jenis pancang, dan petak contoh ukuran $2 \mathrm{~m} \times 2 \mathrm{~m}$ untuk mengumpulkan data jenis semai.

Instrumen penelitian yang digunakan adalah lembar observasi untuk mengumpulkan data penelitian yang meliputi; jenis, jumlah, dan diameter tumbuhan. Kriteria untuk tingkat pohon yaitu memiliki diameter $(1,3 \mathrm{~m})>20 \mathrm{~cm}$, bila pohon berbanir diameter diukur $20 \mathrm{~cm}$ di atas banir. Tiang dengan diameter setinggi dada $(1,3 \mathrm{~m})$ antara $10-20 \mathrm{~cm}$. Pancang, yang tingginya $>1,5 \mathrm{~m}$ dengan diameter $<10 \mathrm{~cm}$, dan semai dengan tinggi < 1,5 m (Subiandono dkk, 2010). Data struktur dan komposisi vegetasi dianalisis secara deskriptif kuantitatif untuk menentukan Kerapatan Relatif/KR, Dominasi Relatif/DR, Frekuensi Relatif/FR, dan Indeks Nilai Penting/INP (Alimuddin, 2011).

\section{HASIL PENELITIAN DAN PEMBAHASAN}

Hutan di Desa Ranga-ranga Kecamatan Masama Kabupaten Banggai yang digunakan sebagai lokasi penelitian berada pada ketinggian $23 \mathrm{mdpl}$. Berdasarkan hasil penelitian yang telah dilakukan, diperoleh vegetasi tingkat pohon sebanyak 46 individu dari 12 jenis, tingkat tiang sebanyak 25 individu dari 11 jenis, tingkat pancang sebanyak 97 individu dari 25 jenis dan tingkat semai sebanyak 223 individu dari 21 jenis vegetasi. Data jenis, famili, jumlah dan indeks nilai penting spesies tiap tingkatan vegetasi dijabarkan pada Tabel 1, Tabel 2, Tabel 3, dan Tabel 4 berikut. 
Tabel 1. Vegetasi dan Indeks Nilai Penting Tumbuhan Angiospermae Tingkat Pohon yang Terdapat pada Area Penelitian

\begin{tabular}{llccccc}
\hline \multicolumn{1}{c}{ Nama Tumbuhan } & Famili & Jumlah & FR & KR & DR & INP \\
\hline Musa paradisiaca & Mucaceae & 7 & 10,5 & 15,2 & 7,38 & 33,08 \\
Anacardium occidentale & Anacardiaceae & 11 & 31,03 & 23,92 & 4,9 & 59,85 \\
Tectona grandis & Verbenaceae & 10 & 5,8 & 21,7 & 16,15 & 43,65 \\
Morinda citrifolia & Rubiaceae & 2 & 3,44 & 4,34 & 5,4 & 13,18 \\
Giricidia sepium & Fabaceae & 5 & 6,9 & 10,87 & 5,28 & 23,05 \\
Dysoxylum cauliflorum & Meliaceae & 5 & 10,34 & 10,87 & 7,76 & 28,97 \\
Artocarpus altilis & Moraceae & 1 & 3,44 & 2,18 & 13,63 & 19,25 \\
Metroxylon sagu & Arecaceae & 1 & 3,44 & 2,18 & 11,39 & 17,01 \\
Artocarpus heterophyllus & Moraceae & 1 & 3,44 & 2,18 & 11,82 & 17,44 \\
Ficus benjamina & Moraceae & 1 & 3,44 & 2,18 & 15,23 & 20,85 \\
Pterocarpus indicus & Fabaceae & 1 & 3,44 & 2,18 & 7,52 & 13,14 \\
Muntingia calabura & Muntingiaceae & 1 & 3,44 & 2,18 & 4,91 & 10,53 \\
\hline
\end{tabular}

Tabel 2. Vegetasi dan Indeks Nilai Penting Tumbuhan Angiospermae Tingkat Tiang yang Terdapat pada Area Penelitian

\begin{tabular}{llccccc}
\hline \multicolumn{1}{c}{ Nama Tumbuhan } & \multicolumn{1}{c}{ Famili } & Jumlah & FR & KR & DR & INP \\
\hline Musa paradisiaca & Mucaceae & 2 & 8,7 & 8 & 12,93 & 29,63 \\
Anacardium occidentale & Anacardiaceae & 3 & 8,7 & 12 & 5,41 & 26,11 \\
Giricidia sepium & Fabaceae & 4 & 17,39 & 16 & 6,99 & 40,38 \\
Tabernaemontana pauciflora & Apocynaceae & 1 & 4,35 & 4 & 10,07 & 18,42 \\
Ficus septica & Moraceae & 5 & 17,39 & 20 & 8,77 & 46,16 \\
Guettarda speciosa & Rubiaceae & 1 & 4,35 & 4 & 7,56 & 15,91 \\
Theobroma cacao & Malvaceae & 4 & 17,39 & 16 & 4,93 & 38,32 \\
Mangifera indica & Anacardiaceae & 1 & 4,35 & 4 & 4,67 & 13,02 \\
Cordia dichotoma & Boraginaceae & 1 & 4,35 & 4 & 13,7 & 22,05 \\
Kleinhovia hospital & Malvaceae & 2 & 8,7 & 8 & 5,91 & 22,61 \\
Toona sureni & Meliaceae & 1 & 4,35 & 4 & 7,56 & 15,91 \\
\hline
\end{tabular}

Tabel 3. Vegetasi dan Indeks Nilai Penting Tumbuhan Angiospermae Tingkat Pancang yang Terdapat pada Area Penelitian

\begin{tabular}{llcccc}
\hline \multicolumn{1}{c}{ Nama Tumbuhan } & \multicolumn{1}{c}{ Famili } & Jumlah & FR & KR & INP \\
\hline Musa paradisiaca & Musaceae & 10 & 6,5 & 10,3 & 16,8 \\
Anacardium occidentale & Anacardiaceae & 4 & 5,2 & 4,12 & 9,32 \\
Tectona grandis & Lamiaceae & 2 & 2,6 & 2,06 & 4,66 \\
Manihot esculenta & Euphorbiaceae & 13 & 9,1 & 13,4 & 22,5 \\
Pandanus tectorius & Pandanaceae & 2 & 2,6 & 2,06 & 4,66 \\
Calamus rotang & Arecaceae & 6 & 6,5 & 6,18 & 12,68 \\
Giricidia sepium & Fabaceae & 8 & 7,8 & 8,24 & 16,04 \\
Tabernaemontana pauciflora & Apocynaceae & 6 & 7,8 & 6,18 & 13,98 \\
Chamaedorea elegans & Arecaceae & 5 & 6,49 & 5,15 & 11,64 \\
Ficus septica & Moraceae & 3 & 3,9 & 3,09 & 6,99 \\
\hline
\end{tabular}




\begin{tabular}{llcccc}
\hline \multicolumn{1}{c}{ Nama Tumbuhan } & \multicolumn{1}{c}{ Famili } & Jumlah & FR & KR & INP \\
\hline Psidium guajava & Myrtaceae & 6 & 5,2 & 6,18 & 11,38 \\
Dysoxylum cauliflorum & Meliaceae & 2 & 2,6 & 2,06 & 4,66 \\
Guettarda speciosa & Rubiaceae & 3 & 3,9 & 3,09 & 6,99 \\
Ricinius communis & Euphorbiaceae & 1 & 1,29 & 1,04 & 2,33 \\
Metroxylon sagu & Arecaceae & 1 & 1,29 & 1,04 & 2,33 \\
Averrhoa carambola & Oxalidaceae & 1 & 1,29 & 1,04 & 2,33 \\
Thebroma cacao & Malvaceae & 2 & 1,29 & 2,11 & 3,4 \\
Mangifera indica & Anacardiaceae & 1 & 1,29 & 1,04 & 2,33 \\
Artocarpus heterophyllus & Moraceae & 1 & 1,29 & 1,04 & 2,33 \\
Syzygium lineatum & Myrtaceae & 1 & 1,29 & 1,04 & 2,33 \\
Kleinhovia hospital & Malvaceae & 5 & 6,49 & 5,15 & 11,64 \\
Caesalpinia pulcherrima & Fabaceae & 1 & 1,29 & 1,04 & 2,33 \\
Coffea Arabica & Rubiaceae & 8 & 6,49 & 8,25 & 14,74 \\
Muntingia calabura & Muntingiaceae & 1 & 1,29 & 1,04 & 2,33 \\
Mallotus paniculatus & Euphorbiaceae & 4 & 5,2 & 4,12 & 9,32 \\
\hline
\end{tabular}

Tabel 4. Vegetasi dan Indeks Nilai Penting Tumbuhan Angiospermae Tingkat Semai yang Terdapat pada Area Penelitian

\begin{tabular}{llcccc}
\hline \multicolumn{1}{c}{ Nama Tumbuhan } & \multicolumn{1}{c}{ Famili } & Jumlah & FR & KR & INP \\
\hline Ananas comocus & Bromeliaceae & 6 & 2,81 & 2,7 & 5,51 \\
Piper betle & Piperaceae & 12 & 9,86 & 5,38 & 15,24 \\
Musa paradisiaca & Musaceae & 3 & 2,81 & 1,35 & 4,16 \\
Mimosa pudica & Fabaceae & 4 & 2,81 & 1,8 & 4,61 \\
Pandanus amarillyfolius & Pandanaceae & 7 & 2,81 & 3,14 & 5,95 \\
Cyperus ratundus & Cyperaceae & 70 & 7,04 & 31,39 & 38,43 \\
Ficus septica & Moraceae & 3 & 4,22 & 1,35 & 5,57 \\
Sphagneticola trilobata & Asteraceae & 20 & 7,04 & 8,97 & 16,01 \\
Psidium guajava & Myrtaceae & 3 & 2,81 & 1,35 & 4,16 \\
Aglaonema simplex & Araceae & 7 & 1,41 & 3,13 & 4,54 \\
Ricinius communis & Euphorbiaceae & 9 & 8,45 & 4,03 & 12,48 \\
Aster amellus & Asteraceae & 7 & 2,81 & 3,13 & 5,95 \\
Colocasia esculenta & Araceae & 4 & 2,81 & 1,8 & 4,61 \\
Theobroma cacao & Malvaceae & 9 & 12,68 & 4,03 & 16,71 \\
Caesalpinia pulcherrima & Fabaceae & 2 & 2,81 & 0,89 & 3,71 \\
Coffea Arabica & Rubiaceae & 2 & 2,81 & 0,89 & 3,71 \\
Alpinia galangal & Zingiberaceae & 6 & 2,81 & 2,7 & 5,51 \\
Imperata cylindrical & Poaceae & 23 & 5,63 & 10,37 & 16 \\
Dieffenbachia seguine & Araceae & 3 & 2,81 & 1,35 & 4,16 \\
Eleusine indica & Poaceae & 12 & 5,63 & 5,38 & 11,01 \\
Sphagneticola trilobata & Asteraceae & 11 & 7,04 & 4,93 & 11,97 \\
\hline
\end{tabular}

Data di atas menunjukkan bahwa struktur dan komposisi jenis vegetasi yang berada di dalam plot pengamatan yaitu sebanyak 391 individu dari 45 jenis. Dari 45 jenis tersebut hanya ditemukan 1 jenis tumbuhan yang mempunyai tingkat vegetasi lengkap mulai dari tingkat semai, pancang, tiang dan 
pohon, yaitu jenis awar-awar (Ficus septica). Sedangkan 44 jenis lainnya tidak mempunyai tingkat vegetasi yang lengkap. Jenis pertumbuhan yang tidak lengkap pada setiap tingkatan dapat disebabkan oleh berbagai kemungkinan, seperti adanya jenis-jenis tertentu yang hilang dan mati diakibatkan keadaan tempat tumbuh terganggu dan ada pula jenis tersebut berada diluar petak pengamatan.

Variasi distribusi dipengaruhi oleh kemampuan tumbuhan untuk bertahan hidup dan bereproduksi secara maksimum karena kompetisi spesies menyebabkan dominasi dan mempengaruhi spesies tumbuhan yang rentan terhadap persaingan antar spesies (Hailu, 2017). Perbedaan jumlah, spesies, famili, total luas bidang dasar, dan komposisi vegetasi disebabkan karena perbedaan pengaruh lingkungan lokal seperti gradien gangguan dan karakteristik vegetasi (Bhatt and Khanal, 2010). Penyebar luasan suatu famili juga dapat ditentukan oleh jumlah benih, kemampuan penyebaran, dan berbagai toleransi ekologi (Al-mayah et al., 2018).

Spesies yang paling banyak ditemukan pada plot pengamatan adalah vegetasi tingkat semai yaitu jenis rumput teki (Cyperus rotundus). Jumlah spesies Cyperus rotundus yang diperoleh pada petak pengamatan lebih banyak dibandingkan jenis lainnya yaitu sebanyak 70 individu sebagaimana yang tercantum pada Tabel 4. Teki tumbuh liar ditempat terbuka atau sedikit terlindung dari sinar matahari pada lapangan rumput, pinggir jalan, tegalan, atau lahan petanian yang tumbuh sebagai gulma yang sukar diberantas (Dalimartha, 2009). Berdasarkan jumlah kehadiran familinya, vegetasi hutan yang berada di Desa Ranga-ranga Kecamatan Masama Kabupaten Banggai didominasi oleh famili Moraceae. Secara ekologi, lingkungan yang ada di Desa Ranga-ranga mendukung spesies dari famili tersebut tumbuh dan berkembang biak. Kondisi lingkungan di daera tersebut memiliki topografi dataran rendah dan perbukitan, dengan ketinggian sekitar 23 mdpl. Menurut Tjitrosoepomo (2009), famili Moraceae termasuk famili tumbuhan yang tersebar di daerah tropis sampai subtropis. Morus, Artocarpus dan Ficus merupakan tiga genus terbesar Moraceae.

Hasil penelitian menunjukkan bahwa nilai frekuensi relatif (FR) tertinggi sebesar 31,03\% adalah jenis Anacardium occidentale tingkat pohon, nilai FR terendah sebesar 1,29\% adalah jenis Ricinius communis, Metroxylon sagu, Averrhoa carambola, Theobroma cacao, Mangifera indica, Artocarpus heterophyllus, Syzygium lineatum, Caesalpinia pulcherrima, dan Muntingia calabura tingkat pancang. Nilai kerapatan relatif (KR) terbesar adalah 31,39\% pada jenis Cyperus rotundus tingkat semai, nilai KR terendah sebesar 0,89\% pada jenis Caesalpinia pulcherima dan Coffea Arabica tingkat semai. Nilai kerapatan suatu jenis vegetasi menunjukkan jumlah individu jenis vegetasi bersangkutan pada satuan luas tertentu, maka nilai kerapatan merupakan gambaran mengenai jumlah jenis vegetasi tersebut pada masing-masing tipe ekosistem atau tipe vegetasi hutan (Gunawan et al., 2011). Perbedaan kemampuan reproduksi, penyebaran dan daya adaptasi terhadap lingkungan dapat dilihat dari perbedaan nilai kerapatan masing-masing tumbuhan. Nilai kerapatan merupakan gambaran mengenai jumlah spesies tersebut pada lokasi penelitian, sehingga kerapatan suatu spesies menunjukkan jumlah spesies yang besangkutan pada luasan tertentu (Umar, 2012). Kerapatan merupakan faktor yang berpengaruh terhadap pertumbuhan pohon, bila kerapatan tinggi maka persaingan untuk mendapatkan unsur hara maupun cahaya matahari semakin besar. Nilai frekuensi menggambarkan pola penyebaran suatu jenis dalam suatu habitat, apabila suatu jenis memiliki nilai frekuensi yang tinggi maka jenis tersebut akan tumbuh secara menyebar dan sebaliknya suatu jenis akan tumbuh berkelompok dan sedikit apabila nilai frekuensinya rendah (Nizar et al., 2016).

Nilai dominansi relatif (DR) tertinggi adalah Tectona grandis sebesar $16,15 \%$ tingkat pohon, nilai DR terendah adalah pada Mangifera indica sebesar 4,67\% tingkat tiang. Dominansi suatu spesies tumbuhan dapat dilihat dari jumlah spesies, ukuran diameter, dan pertumbuhan yang dominan (Umar, 
2012). Dominansi adalah karakteristik dari komunitas yang menyatakan pengaruh penguasaan suatu jenis dalam komunitas terhadap jenis lain sehingga populasi jenis lain relatif akan berkurang dalam jumlah atau daya hidupnya (Martono, 2012). Dominansi menggambarkan luas penutup atau bagian tanah yang dikuasai oleh tumbuhan. Nilai dominasi suatu jenis tumbuhan diperoleh dengan melihat presentase daerah yang ditutupi atau dikuasai oleh jenis tumbuhan (Oktaviani et al., 2017). Penyebaran tumbuhan yang bervariasi dimulai dari tumbuhan penutup tanah, semai, pancang, tiang dan pohon. Pada perkembangannya akan terseleksi melalui tahapan suksesi sehingga jenis yang dominan yang dapat bertahan dalam membentuk formasi tegakan (Tulalessy, 2012). Spesies yang dominan adalah spesies yang berhasil melakukan efisiensi energi yang ada dalam lingkungannya sehingga energi dapat digunakan semaksimal mungkin untuk proses pertumbuhannya dan menjadi dominan dibanding tumbuhan lainnya (Zulharman, 2017).

Hasil analisis Indeks Nilai Penting (INP), menunjukkan bahwa jenis vegetasi tingkat pohon yang memiliki INP tertinggi adalah Anacardium occidentale (INP=59,85\%), sedangkan jenis terendah yaitu Muntingia calabura (INP=10,53\%). Pada tingkat tiang yang memiliki INP tertinggi adalah Ficus septica (INP= 46,16\%), sedangkan jenis terendah yaitu Guettarda speciosa dan Toona sureni (INP 15,91\%). Pada tingkat pancang yang memiliki INP tertinggi adalah Musa paradisiaca (INP=16,8\%), sedangkan jenis terendah yaitu Richinus communis, Averrhoa carambola, Mangifera indica, Artocarpus heterophyllus, Caesalpinia pulcherrima, dan Muntingia calabura (INP=2,33\%). Pada tingkat semai yang memiliki INP tertinggi adalah Cyperus rotundus (INP=38,43\%), sedangkan jenis terendah yaitu Caesalpinia pulcherrima, dan Coffea arabica (INP=3,71\%). Indeks nilai penting menggambarkan besarnya pengaruh yang diberikan oleh suatu spesies dalam komunitas. Jika nilai INP suatu spesies tinggi menunjukkan bahwa spesies tersebut merupakan jenis yang dominan, menyebar luas dan menguasai suatu hutan. Nilai indeks rendah menunjukkan bahwa terdapat tekanan ekologi tinggi, baik yang berasal dari faktor biotik atau faktor abiotik. Tekanan ekologi yang tinggi menyebabkan sebagian jenis tumbuhan tidak dapat bertahan hidup di suatu lingkungan (Nizar et al., 2016).

Indeks nilai penting jenis tumbuhan merupakan salah satu parameter yang menunjukkan peranan jenis tumbuhan tersebut dalam komunitasnya. Selain itu, nilai INP yang tinggi menunjukkan bahwa jenis tersebut mampu merebut zat hara sinar matahari dan ruang tumbuh lebih banyak dari jenis lainnya, sehingga mempengaruhi pertumbuhan dan diameter pohon (Siadari et al., 2013). Spesies tumbuhan yang memiliki indeks nilai penting yang lebih tinggi dari yang lainnya dikarenakan spesies tumbuhan tersebut cukup mendominasi dan menyebar pada seluruh stasiun penelitian sehingga nilai dominasinya tinggi (Hidayat, 2017). Selain karena tumbuhan tersebut mendominasi, tingginya nilai INP suatu jenis tumbuhan disebabkan karena tumbuhan tersebut mempunyai daya adaptasi yang lebih baik dari jenis lainnya (Destaranti et al., 2017). Nilai INP dapat dijadikan sebagai parameter kuantitatif untuk menyatakan tingkat dominansi spesies-spesies dalam suatu komunitas tumbuhan. Spesies yang dominan memiliki nilai INP yang tinggi sehingga memiliki peranan yang paling penting di dalam kawasan tersebut (Nikmah \& Wiryani, 2016). Sebalikanya, INP yang rendah mengindikasikan bahwa jenis-jenis tersebut sangat potensial untuk hilang dari ekosistem jika terjadi tekanan karena jumlahnya sangat sedikit, kemampuan reproduksi rendah dan penyebaran yang sempit (Zulkarnain et al., 2015).

Hasil penelitian sebelumnya yaitu struktur dan komposisi vegetasi Angiospermae di Taman Wisata Wira Garden Lampung diperoleh 20 spesies terdiri atas 139 individu kategori pohon dan 51 individu kategori tiang, sehingga jumlah total 190 individu dalam 14 famili (Umar, 2012). Selain itu, hasil penelitian keanekaragaman jenis tumbuhan Angiospermae yang terdapat di kebun biologi Seungko Mulat Kecamatan Lhoong Aceh Besar ditemukan 7 spesies habitus herba, 13 spesies habitus semak, 
serta 10 spesies habitus pohon (Taib \& Dewi, 2013). Hasil penelitian yang diperoleh (Nizar et al., 2016) menunjukkan bahwa komposisi jenis vegetasi hutan produksi Desa Lembah Mukti beranekaragam, yaitu terdiri dari 169 individu dari 20 jenis vegetasi tingkat pohon, 126 individu dari 18 jenis vegetasi tingkat tiang, 102 individu dari 14 jenis vegetasi tingkat pancang dan 73 individu dari 10 jenis vegetasi tingkat semai. Hasil penelitian tersebut sejalan dengan penelitian ini, dengan kesimpulan bahwa keanekaragaman tumbuhan pada suatu daerah dipengaruhi oleh struktur dan komposisi vegetasi yang ada.

\section{SIMPULAN}

Berdasarkan hasil penelitian menunjukan bahwa nilai frekuensi relatif tertinggi adalah pada Anacardium occidentale ( $\mathrm{FR}=31,03 \%$ ), terendah adalah Ricinius communis, Metroxylon sagu, Averrhoa carambola, Theobroma cacao, Mangifera indica, Artocarpus heterophyllus, Syzygium lineatum, Caesalpinia pulcherrima, dan Muntingia calabura ( $F R=1,29 \%$ ). Nilai kerapatan relatif tertinggi adalah Cyperus rotundus (KR=31,39\%), terendah Caesalpinia pulcherima dan Coffea Arabica (KR=0,89\%). Nilai dominansi relatif tertinggi adalah Tectona grandis ( $\mathrm{DR}=16,15 \%$ ), terendah adalah Mangifera indica (DR=4,67\%). Indeks Nilai Penting tertinggi adalah Anacardium occidentale (INP=59,85\%), terendah adalah Richinus communis, Averrhoa carambola, Mangifera indica, Artocarpus heterophyllus, Caesalpinia pulcherrima, dan Muntingia calabura (INP=2,33\%).

\section{UCAPAN TERIMA KASIH}

Ucapan terima kasih kepada seluruh pihak yang telah membantu baik saat pengambilan data di lapangan maupun saat analisis data dan penyusunan laporan sehingga penelitian kami dapat berjalan dengan baik dan lancar.

\section{RUJUKAN}

Alimuddin, L, O. (2011). Analisis Daya Lenting Vegetasi Hutan Produksi pada Kawasan Penambangan Biji Nikel PT. Aneka Tambang Tbk. di Konawe Utara. Jurnal Agriplus, 21(1), 83-93. Retrieved from https://adoc.tips/analisis-daya-lenting-vegetasi-hutan-produksi-pada-kawasan-p.html

Asmayannur, I. (2012). Analisis Vegetasi Dasar di Bawah Tegakan Jati Emas (Tectona grandis) dan Jati Putih (Gmelina arborea) di Kampus Universitas Andalas. Jurnal Biologi Universitas Andalas, 1(2), 172-177. Retrieved from http://jbioua.fmipa.unand.ac.id/index.php/jbioua/article/download/29/26

Bhatt, R. P., and Khanal, S. N. (2010). Vegetation Analysis and Differences in Local Environment Variables in Indrawati Hydropower Project Areas in Nepal. Journal of Plant Science, 1(4), 83-94. Retrieved from https://www.researchgate.net/publication/228767607

Dalimartha, S. (2009). Atlas Tumbuhan Obat Indonesia Jilid 1. Jakarta: Trubus Agriwidya.

Destaranti, N., Sulistyani, S., \& Yani, E. (2017). Struktur dan Vegetasi Tumbuhan Bawah pada Tegakan Pinus di RPH Kalirajut dan RPH Baturraden Banyumas. Scripta Biologica, 4(3), 155. https://doi. org/10.20884/1.sb.2017.4.3.407

Djamal, Z. \& I. (2012). Prinsip-Prinsip Ekologi (Ekosistem, Lingkungan, dan Pelestariannya). Jakarta: Bumi Aksara.

Gunawan, W., Basuni, S., Indrawan, A., Prasetyo, L. B., \& Soedjito, H. (2011). Analisis Komposisi Dan Struktur Vegetasi Terhadap Upaya Restorasi Kawasan Hutan Taman Nasional Gunung Gede Pangrango. Jurnal Pengelolaan Sumberdaya Alam Dan Lingkungan, 1(2), 93. https://doi.org/10. 29244/jpsl.1.2.93

Hailu, H. (2017). Analysis Of Vegetation Phytosociological Characteristics And Soil Physico-Chemical Conditions In Harishin Rangelands Of Eastern Ethiopia. Land, 6(1). https://doi.org/10.3390/land60 
10004

Heriyanto, N. M., \& Subiandono, E. (2016). Studi Ekologi Dan Potensi Geronggang (Cratoxylon Arborescens BI.) Di Kelompok Hutan Sungai Bepasir-Sungai Siduung, Kabupaten Tanjung Redeb, Kalimantan Timur. Buletin Plasma Nutfah, 13(2), 82. https://doi.org/10.21082/blpn.v13n2. 2007.p82 -87

Hidayat, M. (2017). Analisis Vegetasi dan Keanekaragaman Tumbuhan di Kawasan Manifestasi Geotermal le Suum Kecamatan Mesjid Raya Kabupaten Aceh Besar. Jurnal Biotik, 5(2), 114 124. Retrieved from http://jurnal.ar-raniry.ac.id/index.php/biotik/article/view/3019/2159

Indrawan. (2007). Biologi Konservasi. Jakarta: Yayasan Obor Indonesia.

Indriyanto. (2012). Ekologi Hutan. Jakarta: Bumi Aksara.

Kusmana, C., \& Hikmat, A. (2015). The Biodiversity of Flora in Indonesia. Journal of Natural Resources and Environmental Management, 5(2), 187-198. https://doi.org/10.19081/jpsl.5.2.187

Martono, D. S. (2012). Analisis Vegetasi Dan Asosiasi Antara Jenis-Jenis Pohon Utama Penyusun Hutan Tropis Dataran Rendah Di Taman Nasional Gunung Rinjani Nusa Tenggara Barat. AgriTek, 13(2), 18-27. Retrieved from http://www.unmermadiun.ac.id/repository_jurnal_penelitian/Jur nal\%20Agritek/

Nikmah, N., \& Wiryani, E. (2016). Struktur Komposisi Tumbuhan Bawah Tegakan Jati Di Kebun Benih Klon (KBK) Padangan Bojonegoro. Jurnal Biologi, 5(1). Retrieved from https://ejournal3.undip.ac. id/index.php/biologi/article/view/19479

Nizar, M., Malik, A., \& Wahid, A. (2016). Studi Komposisi Dan Potensi Vegetasi Hutan Produksi Di Wilayah KPHP Model Dampelas Tinombo Desa Lembah Mukti Kecamatan Dampelas Kabupaten Donggala. Jurnal Warta Rimba, 4(1), 65-73. Retrieved from http://jurnal.untad.ac.id/jurnal/index.p hp/WartaRimba/article/view/7281

Oktaviani, S. I., Hanum, L., \& Negara, Z. (2017). Analisis Vegetasi Di Kawasan Terbuka Hijau Industri Gasing. Jurnal Penelitian Sains, 19(3), 124-131. Retrieved from http://ejurnal.mipa.unsri.ac.id/in dex.php/jps/article/view/500

Pemdes Ranga-ranga. (2019). Data Monografi Desa Ranga-Ranga Kecamatan Masama Kabupaten Banggai. Ranga-Ranga: Pemdes Ranga-ranga.

Ridhwan, M. (2012). Tingkat Keanekaragaman Hayati Dan Pemanfaatannya Di Indonesia. Jurnal Biology Education, 1(1), 1-17. Retrieved from https://ojs.serambimekkah.ac.id/index.php/jurnalbio logi/article/view/157

Siadari, T. P., Hilmanto, R., \& Hidayat, W. (2013). Potensi Kayu Rakyat Dan Strategi Pengembangannya (Studi Kasus) Di Hutan Rakyat Desa Buana Sakti Kecamatan Batanghari Kabupaten Lampung Timur. Jurnal Sylva Lestari, 1(1), 75-84. https://doi.org/10.23960/jsl1175-84 Suryabrata, S. (2013). Metodologi Penelitian. Jakarta: Rajawali Press.

Susanti, A. (2016). Analisis Vegetasi Herba Di Kawasan Daerah Aliran Sungai Krueng Jreue Kecamatan Indrapuri Kabupaten Aceh Besar Sebagai Referensi Matakuliah Ekologi Tumbuhan [Universitas Islam Negeri Ar-Raniry Darussalam]. Retrieved from https://repository.arraniry .ac.id/62/

Taib, E. N \& Dewi, C. R. (2013). Keanekaragaman Jenis Tumbuhan Angiospermae Di Kebun Biologi Desa Seungko Mulat. Jurnal Bioma, 2(1), 18-31. Retrieved from http://journal.upgris.ac.id/index .php/bioma/article/download/394/354.\%0A\%0A

Tjitrosoepomo, G. (2009). Morfologi Tumbuhan. Yogyakarta: Gadjah Mada University Press.

Tulalessy, H, A. (2012). Potensi Flora Di Kabupaten Seram Bagian Barat. Jurnal Ekosains, 01(1), 6. Retrieved from https://ejournal.unpatti.ac.id/ppr_paperinfo_Ink.php?id=406

Umar, Z, U. (2012). Analisis Vegetasi Angiospermae Di Taman Wisata Wira Garden Lampung [Universitas Islam Negeri Raden Intan Lampung]. Retrieved from http://repository.radenintan.ac. $\mathrm{id} / 3072 /$

Zulharman. (2017). Analisis Vegetasi Tumbuhan Asing Invasif (Invasive Species) Pada Kawasan Revitalisasi Hutan, Blok Argowulan, Taman Nasional Bromo Tengger Semeru. Natural B, 4(1), 
78-87. Retrieved from https://natural-b.ub.ac.id/index.php/natural-b/article/download/393/pdf Zulkarnain, Alimuddin, L. O., \& Razak, A. (2015). Analisis Vegetasi Dan Visualisasi Profil Vegetasi Hutan Di Ekosistem Hutan Tahura Nipa-Nipa Di Kelurahan Mangga Dua Kota Kendari. Ecogreen, I(1), 43-54. Retrieved from http://ojs.uho.ac.id/index.php/green/article/view/2781 